\title{
Encapsulation of Lactobacillus acidophilus and different prebiotic agents by external ionic gelation followed by freeze-drying
}

\author{
Gabriela Poletto ${ }^{1}$ Bruna de Souza Fonseca ${ }^{1}$ Greice Carine Raddatz ${ }^{1}$ Roger Wagner ${ }^{1}$ \\ Eduardo Jacob Lopes ${ }^{1}$ Juliano Smanioto Barin ${ }^{1}$ Erico Marlon de Moraes Flores ${ }^{2}$ \\ Cristiano Ragagnin de Menezes $^{1^{*}}$ (iD)
}

'Departamento de Ciência e Tecnologia de Alimentos, Universidade Federal de Santa Maria (UFSM), 97105-900, Santa Maria, RS, Brasil. E-mail: cristiano.ufsm@gmail.com. "Corresponding author.

${ }^{2}$ Departamento de Farmácia, Universidade Federal de Santa Maria (UFSM), Santa Maria, RS, Brasil.

ABSTRACT: The aim of this study was to investigate the influence of the addition of prebiotics rice bran, inulin and hi-maize, on the survival of Lactobacillus acidophilus in alginate microparticles obtained by external ionic gelation followed by freeze-drying. The microparticles size ranged from 127.5 $\mu \mathrm{m}$ to $234.6 \mu \mathrm{m}$. Microparticles added from the different prebiotics demonstrated an increase in the protection of the microorganism, which presented greater viability against the gastrointestinal simulation. As for storage under different conditions, rice bran treatment at $25^{\circ} \mathrm{C}$ kept probiotics viable for 30 days. Under storage conditions $-18^{\circ} \mathrm{C}$ and $7^{\circ} \mathrm{C}$, treatments containing prebiotics hi-maize and rice bran maintained viable probiotic microorganisms for a period of 60 days.

Key words: microencapsulation, probiotics, rice bran, inulin, hi-maize.

Encapsulação de Lactobacillus acidophilus e diferentes agentes prebióticos por gelificação iônica externa seguida de liofilização

RESUMO: O objetivo desse estudo foi investigar a influência da adição dos prebióticos farelo de arroz, inulina e hi-maize, na sobrevivência de Lactobacillus acidophilus em micropartículas de alginato obtidas por gelificação externa seguida de liofilização. Analisou-se o tamanho das micropartículas, a viabilidade, em simulação gastrointestinal e estabilidade, durante armazenamento. O tamanho das micropartículas variou de $127.5 \mu \mathrm{m}$ a 234.6 $\mathrm{m}$. As micropartículas adicionadas dos diferentes prebióticos demonstraram um aumento na proteção do microrganismo, que apresentou maior viabilidade frente à simulação gastrointestinal. Quanto ao armazenamento em diferentes condições, a $25^{\circ} \mathrm{C}$ o tratamento farelo de arroz manteve os probióticos viáveis por 30 dias. Nas condições de armazenamento $-18^{\circ} \mathrm{C}$ e $7^{\circ} \mathrm{C}$ os tratamentos contendo os prebióticoshi-maize e farelo de arroz mantiveram os microrganismos probióticos viáveis por um período de 60 dias.

Palavras- chave: microencapsulação, probióticos, farelo de arroz, inulina, hi-maize.

\section{INTRODUCTION}

Functional foods are those that, in addition to the basic nutritional functions, when consumed as part of the usual diet, produce metabolic, physiological and/or beneficial effects on health, preventing chronic, degenerative and cardiovascular diseases, among others (MARTIROSYAN \& SINGH, 2015). Thus, consumption of these foods has been growing worldwide, with emphasis on probiotics.

Probiotics are defined as live microbial food ingredients that, when ingested in adequate amounts, alter intestinal microbiota and confer benefits on host health (HILL et al., 2014). However, a great challenge in the incorporation of probiotic bacteria in food is the maintenance of its viability during processing, packaging, storage conditions and passage through gastrointestinal tract (POP et al., 2015; BARBOSA \& TEIXEIRA, 2017). Thus, microencapsulation appears as a viable alternative for the protection of probiotics, conferring greater viability to strains and greater effectiveness of probiotic action due to controlled release (ARGIN et al., 2014).

Among techniques ofmicroencapsulation of probiotics,external ionic gelation/extrusion is the most popularly used, since it presents simple and accessible conditions for microparticles production, since it does not use temperature and solvent (RIBEIRO et al., 2014). Drying of 
microparticles is an important factor in improving storage properties of capsules due to water removal and ease of use and homogeneous distribution throughout the product (MORTAZAVIAN \&SOHRABVANDI, 2007). Use of prebiotics in capsule may increase viability of probiotic microorganisms, since they may stimulate probiotic multiplication and/or activity during processing and storage (JANTARATHIN et al., 2017).

Therefore, the aim of this study was to evaluate the viability of Lactobacillus acidophilus in alginate microparticles containing different prebiotic sources (rice bran, inulin and hi-maize) produced by external ionic gelation technique followed by freeze-drying when exposed to simulated gastrointestinal conditions and storage at different temperatures.

\section{MATERIALS AND METHODS}

Microencapsulation by the external ionic gelation and freeze-drying process

Microparticles were produced according to the extrusion technology developed by ETCHEPARE et al., (2016). For this, an airbrush (nozzle size: $0.3 \mathrm{~mm}$ ) model EW 110 was coupled to an air compressor model $\mathrm{MB} 24 / \mathrm{BV}$, at the air pressure of $2.72 \mathrm{kgf} / \mathrm{cm}^{2}$, using the height of $30 \mathrm{~cm}$ between atomization nozzle and $\mathrm{CaCl}_{2}$ solution.

Four solutions containing 2\% sodium alginate (Vetec, Rio de Janeiro, Brazil), 10\% prebiotic and $100 \mathrm{ml}$ sterile distilled water were prepared in the following formulations: sodium alginate (ALGL); sodium alginate+rice bran (AFAL); and sodium alginate+inulin (AINL) and sodium alginate+hi-maize (National Starch, Bridgewater, USA) (AHML). After complete dispersion of the polymers, strains of L. acidophilus were added and solutions (ALGL, AFAL, AHML and $\mathrm{AINL}$ ) were sprayed into $0.1 \mathrm{M} \mathrm{CaCl}_{2}$ (Vetec, Rio de Janeiro, Brazil).

After microparticles produced were frozen $\left(-18^{\circ} \mathrm{C}\right.$ for $\left.24 \mathrm{~h}\right)$ on the same day they were produced. Frozen microparticles $\left(-18^{\circ} \mathrm{C}\right)$ were freezedrying in a Liotop L101 lyophilizer (São Carlos, São Paulo, Brazil) and removed from the freezer 24 hours later (vacuum: $0.200-0.300 \mu \mathrm{Hg}$ and condenser temperature $-37^{\circ} \mathrm{C}$ ).

\section{Morphology and particle size distribution}

Morphology of dried microparticles was evaluated using a Scanning Electron Microscope (JEOL, model JM6360). Microparticles were fixed with a double-sided tape in aluminum beads and covered with a thin layer of gold.

Particle size distribution was performed by laser diffraction after dispersion in water of the dried microparticles in Mastersizer 2000 equipment (Malvern, Germany). The particle size results reflected the mean diameter of the microparticles analyzed (D [4: 3]), resulting from ten replicates made by the apparatus.

\section{Enumeration of microencapsulated Latobacillus acidophilus}

Viable cell count was performed according to the methodology proposed by SHEU, MARSHALL (1993) with modifications, where 0.1gram of dried microparticles was added in $9 \mathrm{ml}$ of phosphate buffer solution $(0.1 \mathrm{M}, \mathrm{pH} 7,5)$ followed by homogenization. Then samples were diluted in series with peptone

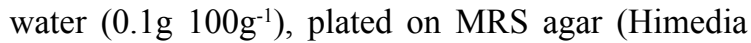
Curitiba, Paraná, Brazil) and incubated at $37^{\circ} \mathrm{C}$ for 72h. After incubation, viable probiotic cells were enumerated and results expressed in colony forming units per gram $\left(\log \mathrm{CFUg}^{-1}\right)$.

Viability of free and microencapsulated Lactobacillus acidophilus exposed to simulated gastrointestinal conditions

Simulation of gastrointestinal conditions was performed according to the method proposed by MADUREIRA et al. (2011) with modifications. Therefore, the microparticles were submitted to different $\mathrm{pHs}$, simulating sections of gastrointestinal tract, such as esophagus/stomach (addition of pepsin, $\mathrm{pH}$ adjusted to 2.0 for 90 minutes), duodenum (addition of pancreatin and bile salts, $\mathrm{pH}$ adjusted to 5.0 for $20 \mathrm{~min}$.) and ileum ( $\mathrm{pH}$ adjusted to 7.5 for $90 \mathrm{~min}$.). The analysis was carried out in a shaking refrigerated incubator (TE-421, Tecnal, Piracicaba, Brazil) at $37^{\circ} \mathrm{C}$ to simulate body temperature at agitation conditions (130rpm for esophageal/ stomach assay, and 45rpm for duodenum and ileum assay) to simulate the peristaltic movements of digestive tract. During the procedure, $1 \mathrm{ml}$ aliquots were collected from the fluid after 0 , 90min. (esophagus/stomach), 110min. (duodenum), and 200min. (ileum), and survival of free and microencapsulated Lactobacillus acidophilus was analysed by enumeration on MRS agar.

Viability of Lactobacillus acidophilus at different
storage conditions Microparticles of Lactobacillus acidophilus were stored at room temperature $\left(25^{\circ} \mathrm{C}\right)$, 
refrigeration $\left(7^{\circ} \mathrm{C}\right)$ and freezing $\left(-18^{\circ} \mathrm{C}\right)$ for 75 days and enumerated after $0,15,30,45,60,75,90,105$ and 120 days of storage.

\section{Statistical analysis}

The analyzes were performed in triplicate and results were evaluated by an analysis of variance (ANOVA); followed by Tukey's means comparison test at a level of $5 \%$ significance $(\mathrm{P}<0.05)$, using the Statistica 7 software.

\section{RESULTS AND DISCUSSION}

\section{Morphology and particle size distribution}

It is observed in figure 1, through Scanning Electron Microscopy, that the microparticles presented a rough surface, which can be explained, since the dehydration of gels of freeze-dried polysaccharides can lead to the formation of a porous matrix, similar to a sponge. In the freeze-drying process, microparticles are subjected to low temperatures, leading to the formation of ice crystals and sublimation of ice crystals under reduced pressure, resulting in a porous dry product (DOLLY et al., 2013).

In this study, mean diameter of microparticles of different matrices ranged from $127.5 \pm 1.58-234.6 \pm 2.79 \mu \mathrm{m}$ and the smallest particle size was obtained in AHM treatment while the treatment with the largest mean diameter was AIN. The AIN and ALG treatments did not present significant differences $(\mathrm{P}<0.05)$ among themselves since the size of the alginate microparticles was $233.5 \pm 6.43 \mu \mathrm{m}$. The ARB treatment had a particle size of $224.2 \pm 2.57 \mu \mathrm{m}$. Microparticles within the size range $100-200 \mu \mathrm{m}$ provide an ideal balance, since the larger the microparticles, the better the protection for probiotics, but the worse the sensory effect (NAG et al., 2011).

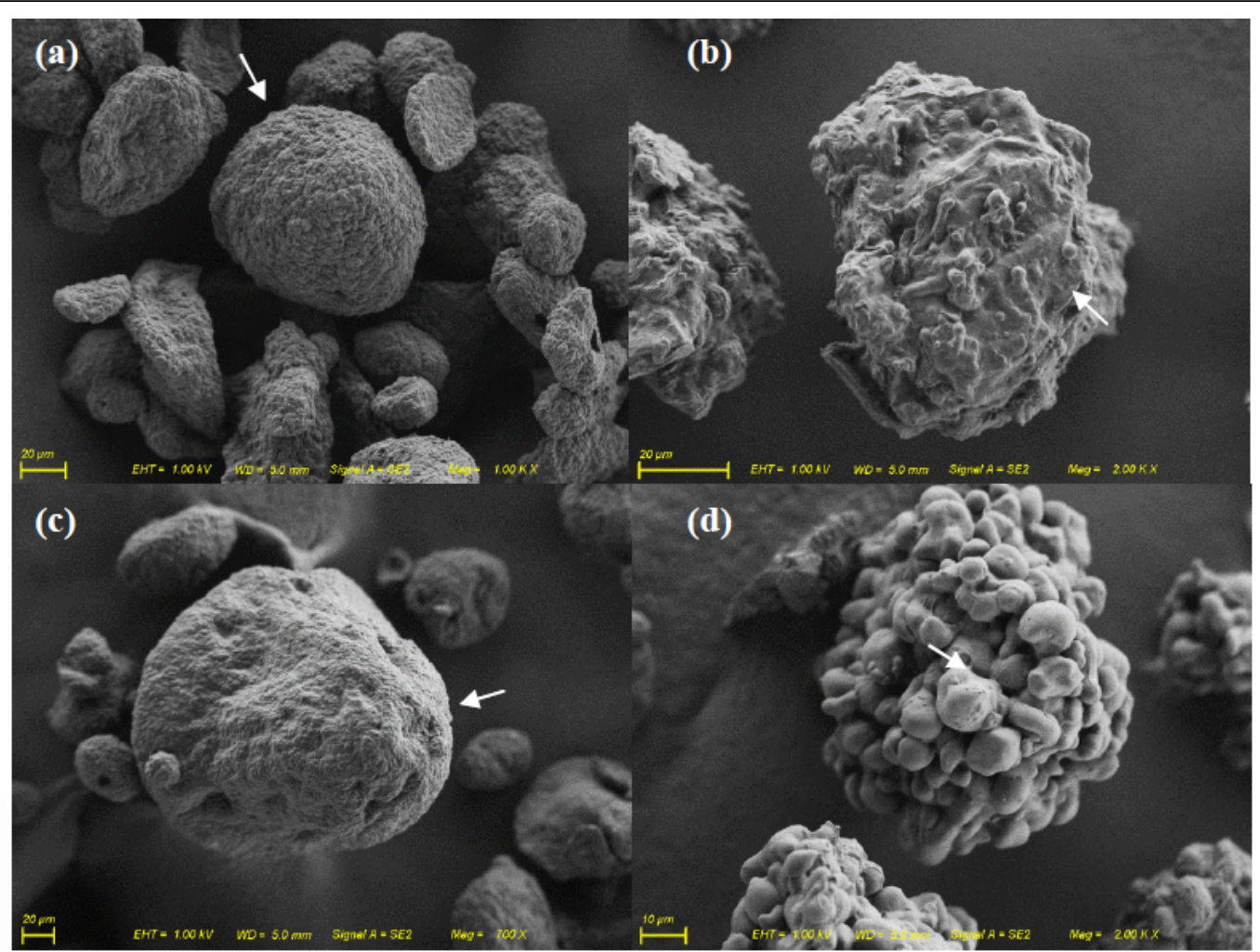

Figure 1 - Scanning electron microscopy (SEM) of alginate microparticles with different prebiotic sources containing Lactobacillus acidophilus obtained by external ionic gelation followed by freeze-drying. (a) $=2 \%$ alginate microparticles (ALG) $(1.00 \mathrm{kx}) ;(b)=2 \%$ alginate microparticles $+10 \%$ rice bran $(\mathrm{ARB})(2.00 \mathrm{kx}) ;(\mathrm{c})=2 \%$ alginate microparticles $+10 \%$ inulin $(\mathrm{AIN})(700 \mathrm{x}) ;(\mathrm{d})=2 \%$ alginate microparticles $+10 \%$ hi-maize (AHM) $(2.00 \mathrm{kx})$. 
Viability of free and microencapsulated Lactobacillus acidophilus exposed to simulated gastrointestinal conditions

Results obtained regarding the survival of the microorganisms under the simulated gastrointestinal conditions are shown in table 1. After $90 \mathrm{~min}$. of incubation, the hydrogenation potential was gradually adjusted with a pepsin solution to a value of 2.0 (esophagus/stomach portion). Survival of probiotics was higher in the alginate microparticles added hi-maize (AHM) compared to the other treatments, since they presented lower release (1.76 log cycles) in relation to their initial count. In another study, CHAN (2011) observed a $4 \log$ reduction in the viability of the freeze-dried Lactobacillus casei microparticles obtained by extrusion with alginate and a reduction of 1.5 to 2 $\log \mathrm{CFUg}^{-1}$ when starch was used in conjunction with alginate, under the same conditions.

After exposure of the free cells to acidic conditions (esophagus/stomach), there was a decrease of $5.35 \log \mathrm{CFUg}^{-1}(\mathrm{p}<0.05)$ in free cells compared to the initial count due to the low $\mathrm{pH}$ in this step process, resulting in low viability of probiotic bacteria. These results corroborated those of DIMITRELLOU et al. (2016), since when the acidic conditions were exposed, Lactobacillus casei ATCC 393 continuously lost its viability, with viable cell counts falling $1.46 \log \mathrm{CFUg}^{-1}$ at $\mathrm{pH} 3$ and 4.03 $\log \mathrm{CFUg}^{-1}$ at $\mathrm{pH} 2$, clearly indicating the need for protection through microencapsulation.

After exposure to simulated duodenal conditions (bile salts, pancreatin and $\mathrm{pH} 5.0$ ), the free cells presented an even more significant drop
$(\mathrm{P}<0.05)$ in the viable cell population $(6.21 \mathrm{log}$ $\mathrm{CFUg}^{-1}$ ) when compared to the initial count. In relation to the microencapsulated microorganism, the treatments did not present a significant difference in comparison with results obtained after the simulation of the acidic conditions, however, there was no total release of the microorganism, since the microparticles promoted its protection.

At the end of the analysis, after exposure to the simulated ileum conditions ( $\mathrm{pH}$ 6.5), the free microorganism presented reduction of $6.69 \mathrm{log}$ $\mathrm{CFUg}^{-1}$ relative to its initial count. This was due to the variation in $\mathrm{pH}$ during the simulation of the gastrointestinal tract, which caused a significant reduction in viability. Conversely, it was observed that the microencapsulation of Lactobacillus acidophilus in alginate, as well as associated with the different prebiotics, gave greater protection to the probiotic during the exposure to the simulation of the gastrointestinal tract, once, after the passage through the ileum, treatments containing alginate, rice bran, inulin and hi-maize presented log reductions of 1.37 , $4.14,1.47$ and 0.72 respectively, when compared with time zero, with significant differences between treatments $(\mathrm{P}<0.05)$.

Results presented in this research corroborated other studies demonstrating the efficiency of microencapsulation in protection of probiotics during exposure to gastrointestinal conditions. PANKASEMSUK et al. (2016) reported that $L$. casei 01 microencapsulated with $2 \%$ alginate and $1 \%$ maize starch allowed optimal survival in both gastric and biliary fluids. In another study, HALIM et al. (2017) compared the viability of free

Table 1 - Survival of free and microencapsulated Lactobacillus acidophilus in different treatments after each step of simulated gastrointestinal conditions.

\begin{tabular}{|c|c|c|c|c|c|}
\hline & Freemicrorganismo & ALG & $\mathrm{ARB}$ & AIN & AHM \\
\hline Initiallog CFU/g & $12.40 \pm 0.02^{\mathrm{aA}}$ & $9.20 \pm 0.29^{\mathrm{aB}}$ & $11.78 \pm 0.05^{\mathrm{aA}}$ & $7.67 \pm 0.02^{\mathrm{aC}}$ & $6.76 \pm 0.08^{\mathrm{aD}}$ \\
\hline $\begin{array}{l}\text { Esophagus/stomach } \\
90 \mathrm{~min} / \mathrm{pH} 2.0\end{array}$ & $7.05 \pm 0.04^{\mathrm{bA}}$ & $6.75 \pm 0.10^{\mathrm{bB}}$ & $6.05 \pm 0.04^{\mathrm{cC}}$ & $4.27 \pm 0.11^{\mathrm{dE}}$ & $5.00 \pm 0.06^{\mathrm{cD}}$ \\
\hline $\begin{array}{l}\text { Duodenum } \\
20 \mathrm{~min} / \mathrm{pH} 5.0\end{array}$ & $6.19 \pm 0.03^{\mathrm{cB}}$ & $7.14 \pm 0.13^{\mathrm{abA}}$ & $6.28 \pm 0.18^{\mathrm{cB}}$ & $4.91 \pm 0.04^{\mathrm{cC}}$ & $5.14 \pm 0.05^{\mathrm{cC}}$ \\
\hline $\begin{array}{l}\text { Ileum } \\
110 \mathrm{~min} / \mathrm{pH} 6.5\end{array}$ & $5.71 \pm 0.06^{\mathrm{dB}}$ & $7.83 \pm 1.69^{\mathrm{abA}}$ & $7.64 \pm 0.02^{\mathrm{bAB}}$ & $6.20 \pm 0.08^{\mathrm{bAB}}$ & $6.04 \pm 0.12^{\mathrm{bAB}}$ \\
\hline
\end{tabular}

$\mathrm{ALG}=2 \%$ alginatemicroparticles; $\mathrm{ARB}=2 \%$ alginatemicroparticles $+10 \%$ rice bran; $\mathrm{AIN}=2 \%$ alginatemicroparticles $+10 \%$ inulin; $\mathrm{AHM}=2 \%$ alginatemicroparticles $+10 \%$ hi-maize.

*Averages followed by the same letter, lowercase in the column and upper case in the row, do not differ statistically from each other by the Tukey test with a significance of $5 \%$. Averages found in triplicate. 
and microencapsulated Pediococcus acidilactici ATCC 8042 in calcium alginate and co-coating with calcium alginate and chitosan by extrusion technique with subsequent freeze-drying using $10 \%(\mathrm{w} / \mathrm{w})$ of skimmed milk as cryoprotectant, compared to simulated gastric juice and bile tolerance assays and reported that probiotic cell mortality significantly reduced when microencapsulated probiotics were compared to free cells.

Viability of Lactobacillus acidophilus at different storage conditions

Table 2 shows the stability of microencapsulated Lactobacillus acidophilus for 75 days of storage under temperatures of $25^{\circ} \mathrm{C}, 7^{\circ} \mathrm{C}$ and $-18^{\circ} \mathrm{C}$, simulating different environmental conditions. At $25^{\circ} \mathrm{C}$, viability of microencapsulated bacteria was maintained until the 15 days of storage for alginate and inulin treatments. Microparticles containing the prebiotics hi-maize and rice bran maintained viability for 15 and 30 days, with counts of $6.02 \pm 0.01 \mathrm{log}$ $\mathrm{CFUg}^{-1}$ and $6.05 \pm 0.03 \log \mathrm{CFUg}^{-1}$, respectively. After this period, there was a significant reduction $(\mathrm{p}<0.05)$ $1.5 \pm 0.01 \log \mathrm{CFUg}^{-1}$ to $\mathrm{ARB}$ and $3.09 \pm 0.03 \mathrm{log}$ $\mathrm{CFUg}^{-1}$ to $\mathrm{AHM}$ in viability of microorganisms until 75 days of storage.

OKURO et al. (2013) also did not obtain positive results at $22^{\circ} \mathrm{C}$ when evaluating solid lipid microparticles in which Lactobacillus acidophilus was co-encapsulated with prebiotic inulin or polydextrose using spray chilling technology, since its stability was evaluated for 120 days and the pre-biotic treatment remained viable for a period of between 0 and 7 days while the treatment containing inulin remained viable between 7 and 30 days and the treatment containing polydextrose remained viable for about 60 days.

As for the freezing effect $\left(-18^{\circ} \mathrm{C}\right)$, alginate (ALG) and inulin (AIN) microparticles were stable

Table 2 - Effect of ambient temperature $\left(25^{\circ} \mathrm{C}\right)$, freezing $\left(-18^{\circ} \mathrm{C}\right)$ and refrigeration $\left(7^{\circ} \mathrm{C}\right)$ on viability of freeze-dryingmicroparticles containing Lactobacillus acidophilus produced with different encapsulation matrices during storage for 75 days.

\begin{tabular}{|c|c|c|c|c|}
\hline Treatments Time (Days) & ALG $\log$ CFU/g & $\mathrm{ARB} \log \mathrm{CFU} / \mathrm{g}$ & AIN $\log$ CFU/g & $\mathrm{AHM} \log \mathrm{CFU} / \mathrm{g}$ \\
\hline 0 & $9.20 \pm 0.29^{\mathrm{aB}}$ & $11.78 \pm 0.05^{\mathrm{aA}}$ & $7.67 \pm 0.02^{\mathrm{aC}}$ & $6.76 \pm 0.08^{\mathrm{aD}}$ \\
\hline 15 & $5.46 \pm 0.37^{\mathrm{bB}}$ & $7.49 \pm 0.31^{\mathrm{bA}}$ & $4.58 \pm 0.23^{\mathrm{Bc}}$ & $6.02 \pm 0.015^{\mathrm{abB}}$ \\
\hline 30 & $2.66 \pm 0.18^{\mathrm{cdD}}$ & $6.05 \pm 0.03^{\mathrm{cA}}$ & $3.13 \pm 0.21^{\mathrm{cBC}}$ & $4.58 \pm 1.31^{\mathrm{bcAB}}$ \\
\hline 45 & $3.21 \pm 0.14^{\mathrm{cC}}$ & $5.67 \pm 0.03^{\mathrm{cA}}$ & $0.00 \pm 0$ & $4.06 \pm 0.04^{\mathrm{cdB}}$ \\
\hline 60 & $2.32 \pm 0.12^{\mathrm{deC}}$ & $5.21 \pm 0.10^{\mathrm{dA}}$ & $0.00 \pm 0$ & $3.83 \pm 0.14^{\mathrm{cdB}}$ \\
\hline 75 & $2.04 \pm 0.02^{\mathrm{eC}}$ & $4.55 \pm 0.09^{\mathrm{eA}}$ & $0.00 \pm 0$ & $2.93 \pm 0.05^{\mathrm{dB}}$ \\
\hline \multicolumn{5}{|c|}{ - } \\
\hline Treatments Time (Days) & ALG $\log \mathrm{CFU} / \mathrm{g}$ & $\mathrm{ARB} \log \mathrm{CFU} / \mathrm{g}$ & $\mathrm{AIN} \log \mathrm{CFU} / \mathrm{g}$ & AHM $\log \mathrm{CFU} / \mathrm{g}$ \\
\hline 0 & $9.20 \pm 0.29^{\mathrm{aB}}$ & $11.78 \pm 0.05^{\mathrm{aA}}$ & $7.67 \pm 0.02^{\mathrm{aC}}$ & $6.76 \pm 0.08^{\mathrm{aD}}$ \\
\hline 15 & $7.32 \pm 0.13^{\mathrm{bB}}$ & $8.54 \pm 0.04^{\mathrm{bA}}$ & $7.49 \pm 0.11^{\mathrm{aB}}$ & $6.31 \pm 0.06^{\mathrm{bC}}$ \\
\hline 30 & $4.75 \pm 0.15^{\mathrm{cD}}$ & $7.07 \pm 0.32^{\mathrm{cA}}$ & $5.40 \pm 0.24^{\mathrm{bC}}$ & $6.32 \pm 0.04^{\mathrm{bB}}$ \\
\hline 45 & $0.00 \pm 0$ & $6.84 \pm 0.08^{\mathrm{cdA}}$ & $0.00 \pm 0$ & $6.25 \pm 0.04^{\mathrm{bB}}$ \\
\hline 60 & $0.00 \pm 0$ & $6.54 \pm 0.11^{\mathrm{dA}}$ & $0.00 \pm 0$ & $6.24 \pm 0.06^{\mathrm{bB}}$ \\
\hline 75 & $0.00 \pm 0$ & $6.12 \pm 0.08^{\mathrm{eA}}$ & $0.00 \pm 0$ & $5.49 \pm 0.13^{\mathrm{bC}}$ \\
\hline \multicolumn{5}{|c|}{ - TemperatureRefrigeration $\left(7^{\circ} \mathrm{C}\right)-$} \\
\hline Treatments Time (Days) & ALG $\log \mathrm{CFU} / \mathrm{g}$ & AFA $\log \mathrm{CFU} / \mathrm{g}$ & AIN $\log \mathrm{CFU} / \mathrm{g}$ & AHM $\log \mathrm{CFU} / \mathrm{g}$ \\
\hline 0 & $9.20 \pm 0.29^{\mathrm{aB}}$ & $11.78 \pm 0.05^{\mathrm{aA}}$ & $7.67 \pm 0.02^{\mathrm{aC}}$ & $6.76 \pm 0.08^{\mathrm{aD}}$ \\
\hline 15 & $6.09 \pm 0.03^{\mathrm{bC}}$ & $6.84 \pm 0.13^{\mathrm{bA}}$ & $3.13 \pm 0.06^{\mathrm{bD}}$ & $6.60 \pm 0.12^{\mathrm{abB}}$ \\
\hline 30 & $3.31 \pm 0.04^{\mathrm{cB}}$ & $6.59 \pm 0.08^{\mathrm{cA}}$ & $0.00 \pm 0$ & $6.44 \pm 0.06^{\mathrm{bA}}$ \\
\hline 45 & $3.27 \pm 0.20^{\mathrm{cB}}$ & $6.28 \pm 0.02^{\mathrm{dA}}$ & $0.00 \pm 0$ & $6.38 \pm 0.04^{\mathrm{bcA}}$ \\
\hline 60 & $0.00 \pm 0$ & $6.23 \pm 0.01^{\mathrm{deA}}$ & $0.00 \pm 0$ & $6.16 \pm 0.06^{\mathrm{cA}}$ \\
\hline 75 & $0.00 \pm 0$ & $6.02 \pm 0.09^{\mathrm{eA}}$ & $0.00 \pm 0$ & $6.15 \pm 0.04^{\mathrm{cA}}$ \\
\hline
\end{tabular}

$\mathrm{ALG}=2 \%$ alginate microparticles; $\mathrm{ARB}=2 \%$ alginate microparticles $+10 \%$ rice bran; $\mathrm{AIN}=2 \%$ alginate microparticles $+10 \%$ inulin; $\mathrm{AHM}=2 \%$ alginate microparticles $+10 \%$ hi-maize.

Averages followed by the same letter, lowercase in the column and upper case in the row, do not differ statistically from each other by the Tukey test with significance of $5 \%$. Averages found in triplicate. 
for 15 days with counts of $7.32 \pm 0.13$ and $7.49 \pm 0.11$ $\log \mathrm{CFUg}^{-1}$ after this period there was a significant reduction $(\mathrm{p}<0.05)$ up to 75 days of storage. The viability reduction at $-18^{\circ} \mathrm{C}$ may be related to the cold-induced injury to the cells, which eventually lead to the probiotic cell death. Microparticles added with AHM showed $6.24 \log \mathrm{CFUg}^{-1}$ in 60 days of storage; however, treatment containing rice bran (ARB) showed better results, giving greater protection, since the microorganism remained viable during 75 days with counts of $6.12 \log \mathrm{CFUg}^{-1}$. In a study by ETCHEPARE et al. (2016), 1\% strength starch (hi-maize) was used for the microencapsulation of Lactobacillus acidophilus in alginate beads by extrusion technique and subsequente freeze-drying, during frozen storage viability of microparticles was maintained for 30 days and 60 days for alginate microparticles $\left(6.61 \pm 0.02 \log \mathrm{CFUg}^{-1}\right)$ and starch resistant (6.05 $\left.\pm 0.06 \log \mathrm{CFUg}^{-1}\right)$, respectively.

In relation to refrigerated storage $\left(7^{\circ} \mathrm{C}\right)$ ARB and AHM treatments obtained counts of $6.02 \pm 0.09$ and $6.15 \pm 0.04 \log \mathrm{CFUg}^{-}$ ${ }^{1}$ during the 75 days of storage. Therefore, use of prebiotics rice bran and hi-maize had a positive effect on the alginate microparticles, increasing the survival of the encapsulated microorganism during storage at $7^{\circ} \mathrm{C}$. SHOJI et al. (2013) used complex coacervation followed by freeze-drying to encapsulate $L$. acidophilus in pectin/casein, applying the microparticles in buffalo milk yogurt. Results indicated that the viability of $L$. acidophilus remained stable for 120 days under refrigeration $\left(7^{\circ} \mathrm{C}\right)$ with counts of $7.23 \log \mathrm{CFUg}^{-1}$.

\section{CONCLUSION}

Alginate microparticles as well as those added from the prebiotics produced by the external extrusion/gelation technique followed by freezedrying promoted the resistance of Lactobacillus acidophilus during the simulation of passage through the gastrointestinal tract. In relation to storage conditions, at the temperatures of $-18^{\circ} \mathrm{C}$ and $7^{\circ} \mathrm{C}$, the best results were obtained in the microparticles containing the prebiotics hi-maize and rice bran; although, rice bran deserves attention, since it is a by product little studied at present and presented excellent results in the protection to maintain probiotic viability. Thus, it is concluded that the himaize and rice bran compounds besides attributing to the microparticles health-promoting prebiotic effects are also capable of increasing the resistance of the L. acidophilus-containing alginate microparticles obtained by external gelation, conferring to these a protective effect and may be alternative means for the development of novel functional foods.

\section{ACKNOWLEDGEMENTS}

This study was financed in part by the Coordenação de Aperfeiçoamento de Pessoal de Nível Superior - Brasil (CAPES) - Finance Code 001".

\section{DECLARATION OF CONFLICTING INTERESTS}

The authors declare no conflict of interest. The founding sponsors had no role in the design of the study; in the collection, analyses, or interpretation of data; in the writing of the manuscript, and in the decision to publish the results.

\section{AUTHORS' CONTRIBUTIONS}

The authors contributed equally to the manuscript.

\section{REFERENCES}

ARGIN, S., et al. The cell release kinetics and the swelling behavior of physically cross linked xanthan echitosan hydrogels in simulated gastrointestinal conditions. Food Hydrocolloids, 40, 138-144, 2014. Available from: <https://www.sciencedirect. com/science/article/pii/S0268005X14000678>. Accessed: Oct. 17, 2017. doi: 10.1016/j.foodhyd.2014.02.018.

BARBOSA, J.; TEIXEIRA, P. Development of probiotic fruit juice powders by spray-drying: A review. Food Reviews International, ISSN 1525-6103. Vol.33, n. ${ }^{\circ} 4$, p.335-358, 2017. Available from: <https://www.tandfonline.com/doi/abs/10.10 80/87559129.2016.1175016>. Accessed: Apr. 14, 2017. doi: 10.1080/87559129.2016.1175016.

CHAN, E. S. Preparation of Ca-alginate beads containing high oil content: Influence of process variables on encapsulation efficiency and bead properties. Carbohydrate Polymers, Volume 84, Issue 4, Pages 1267-1275, 2011. Available from: <https:// www.sciencedirect.com/science/article/pii/S0144861711000397>. Accessed: Jun. 15, 2017. doi: 10.1016/j.carbpol.2011.01.015.

DIMITRELLOU, D. et al. (2016). Survival of spray dried microencapsulated Lactobacillus casei ATCC 393 in simulated gastrointestinal conditions and fermented milk. LWT - Food Science and Technology, v.71, 169-174, 2016. Available from: <https:// www.sciencedirect.com/science/article/pii/S002364381630144X>. Accessed: May 13, 2017. doi: 10.1016/j.lwt.2016.03.007.

DOLLY P. et al. Microencapsulation of Lactobacillus plantarum (mtcc 5422) by spray-freeze-drying method and evaluation of survival in simulated gastrointestinal conditions. Journal of Microencapsulation, v.28(6), p.568-74, 2013. Available from: $<$ https://www.tandfonline.com/doi/full/10.3109/02652048.2011.5994 35>. Accessed: Jun. 11, 2017. doi: 10.3109/02652048.2011.599435.

ETCHEPARE, M. A. et al. Effect of resistant starch (Hi-maize) on the survival of Lactobacillus acidophilus microencapsulated with sodium alginate. Journal of Functional Foods, v.21, p.321-329, 
2016. Available from: <https://www.sciencedirect.com/science/ article/pii/S1756464615006295>. Accessed: Jul. 18, 2017. doi: 10.1016/j.jff.2015.12.025.

HALIM M. et al. Effect of encapsulant and cryoprotectant on the viability of probiotic PediococcusacidilacticiATCC 8042 during freeze-drying and exposure to high acidity, bile salts and heat LWT-Food Science and Technology, Volume 81, p.210-216, 2017. Available from: <https://www.sciencedirect.com/science/ article/pii/S0023643817302232>. Accessed: Nov. 24, 2017. doi: 10.1016/j.lwt.2017.04.009.

HILL C. et al. Expert consensus document. The Internationa Scientific Association for Probiotics and Prebiotics consensus statement on the scope and appropriate use of the term probiotic. Nature Reviews Gastroenterol. Hepatol. v.11(8), p.50614, 2014. Available from: < https://www.nature.com/articles/ nrgastro.2014.66>. Accessed: Aug. 15, 2017. doi: 10.1038/ nrgastro.2014.66

MADUREIRA, A. R. et al. Protective effect of whey cheese matrix on probiotic strains exposed to simulated gastrointestinal conditions. Food Research International, v.44, p.465-470, 2011. Available from: <https://www.sciencedirect.com/science/ article/pii/S0963996910003182>. Accessed: Jun. 19, 2017. doi: 10.1016/j.foodres.2010.09.010.

MARTIROSYAN D. M. ;SINGH J. A new definition of functional food by FFC: what makes a new definition unique? Functional Foods in Health and Disease, v.5(6), p.209-223, 2015. Available from: $<$ http://functionalfoodscenter.net/files/105582267.pdf $>$. Accessed: Apr. 15, 2017.

MORTAZAVIAN, A.M., SOHRABVANDI, S. (Ed.), Probiotics and food probiotic products: Based on dairy probiotic products. Eta Publication, Iran pp. 131-169, 2007.

$\mathrm{NAG}$, A. et al. Microencapsulation of probiotic bacteria using $\mathrm{pH}-$ induced gelation of sodium caseinate and gellan gum. International Dairy Journal, v.21, p.247-253, 2011. Available from: <https://
www.sciencedirect.com/science/article/pii/S0958694610002505>. Accessed: Mar. 15, 2017. doi: 10.1016/j.idairyj.2010.11.002.

OKURO, P. K. et al. Co-encapsulation of Lactobacillus acidophilus with inulin or polydextrose in solid lipid microparticles provides protection and improves stability. Food Research International, v.53, 96-103, 2013. Available from: <https://www.sciencedirect. com/science/article/pii/S0963996913002172>. Accessed: Apr. 9, 2017. doi: 10.1016/j.foodres.2013.03.042.

PANKASEMSUK T. et al. Encapsulation of Lactobacillus casei 01 by alginate along with himaize starch for exposure to a simulated gut model. Food Bioscience, 16, 32-36, 2016. Available from: <https:// www.sciencedirect.com/science/article/abs/pii/S2212429216300463>. Accessed: May 18, 2017. doi: 10.1016/j.fbio.2016.07.001.

POP O. L. et al. The influence of different polymers on viability of Bifidobacterium lactis 300b during encapsulation, freeze-drying and storage. Journal of Food Science and Technology, v.52(7), p.4146-55, 2015. Available from: <https://link.springer.com/article/10.1007/s13197014-1441-4>. Accessed: Jul. 21, 2017. doi: 10.1007/s13197-014-1441-4.

RIBEIRO, M. C. E. et al. Effect of microencapsulation of Lactobacillus acidophilus LA-5 on physicochemical, sensory and microbiological characteristics of stirred probiotic yoghurt. Food Research International, 66, 424-431, 2014. Available from: $<$ https:// www.sciencedirect.com/science/article/pii/S0963996914006656>. Accessed: Mar. 19, 2017. doi: 10.1016/j.foodres.2014.10.019.

SHEU, T. Y. et al. Improving survival of culture bacteria in frozen desserts by microentrapment. Journal of Dairy Science, v.76, p.1902-1907,1993. Available from: <https://www.sciencedirect. com/science/article/pii/S0022030293775232>. Accessed: Feb. 15, 2018. doi: 10.3168/jds.S0022-0302(93)77523-2.

SHOJI, A.S. et al. Viability of L. acidophilus microcapsules and their application to buffalo milk yoghurt. Food and Bioproducts Processing, 9 1, 83-88, 2013. Available from: <https://www. sciencedirect.com/science/article/pii/S0960308512000697>. Accessed: May 20, 2017. doi: 10.1016/j.fbp.2012.08.009. 